\title{
GOITRE PREVALENCE SURVEY IN SCHOOL GOING CHILDREN (6-12 YEARS) OF SRINAGAR DISTRICT OF J \& $\mathrm{K}$.
}

M Rafiq ${ }^{1}$, Rifat Jan², Ashfaq Ahamad³, Yasmeena ${ }^{4}$.

1. Assistant Professor, Department of Community Medicine, SKIMS Medical College, Bemina.

2. Postgraduate Scholar, department of SPM, GMC Srinagar.

3. Lecturer, Department of Community Medicine, SKIMS Medical College, Bemina.

4. Lecturer, Department of Community Medicine, SKIMS Medical College, Bemina.

\section{CORRESPONDING AUTHOR}

\section{Dr M Rafiq MD,}

Department of Community Medicine,

SKIMS Medical College,

Bemina, Srinagar.

Email- Dr.mmrafiq@gmail.com

\section{HOW TO CITE THIS ARTICLE:}

M Rafiq, Rifat Jan, Ashfaq Ahamad, Yasmeena. "Goitre Prevalence Survey in School going Children (6-12 years) of Srinagar district of J \& K". Journal of Evolution of Medical and Dental Sciences 2013; Vol2, Issue 25, June 24; Page: 4630-4637.

\begin{abstract}
Research question: what is the prevalence of goitre in school going children? OBJECTIVE: To assess the magnitude of goitre in the age group of 6-12 years in district Srinagar. STUDY DESIGN: 30-cluster sampling
\end{abstract}

SETTING: schools of Srinagar district

PARTICIPANTS: 6-12 year old children, both boys \& girls.

STATISTICAL ANALYSIS: percentage, rate

RESULTS: Overall prevalence of grade $1^{\text {st }}$ goitre was found in $14.69 \%$ (Girls $16.35 \%$; boys $13.38 \%)$.Grade $2^{\text {nd }}$ goitre was noticed in $0.59 \%$ of surveyed children $(0.96 \%$ in Girls \& $0.29 \%$ in Boys). Total goitre rate (TGR) which is the sum of grade $1^{\text {st }} \&$ Grade $2^{\text {nd }}$ was found in $15.27 \%$ of children. In Girls the rate was higher to an extent of $17 \%$ as compared to Boys were it was $13.67 \%$. As regards magnitude of grade, $1^{\text {st }}$ goitre in different age groups as well as sex differentiation is concerned; we found that grade $1^{\text {st }}$ goitre (both sexes) was more common in the age group of 12 years $(18.70 \%)$ followed by age group of 7 years (15.52\%). In boys, we found that the prevalence of grade $1^{\text {st }}$ was more in age group of 12 years (18.64\%) followed by age group of 9 years $(14.97 \%)$. In girls, the magnitude was found to be higher in the age group of 11 years (20.83\%) followed by age group of 12 years (18.77\%).Maximum TGR (total goitre rate) was found in the age group of 12 years. In boys the maximum involvement was seen in age group of 12 years $(19.49 \%)$ followed by that of 9 years (14.97\%). In girls maximum involvement was found in age group of 11 year's (21.75\%) followed by that of 12 years (20.08\%)

KEY WORDS: Goitre, Total Goitre Rate (TGR), prevalence 


\section{ORIGINAL ARTICLE}

INTRODUCTION: Endemic goitre, one of the earliest non-communicable diseases to humankind, is an important public health problem of worldwide distribution \& the mountainous slopes of Himalayas have been notorious foci of endemic goitre. ${ }^{1}$ We call the condition to be endemic once it affects a large no of population approximately 5\% in periadolescent or preadolescent children ${ }^{2}$. Goitre is prevalent worldwide with over 600 million people having goitre \& 20 million having some degree of brain damage (6 million are cretins) caused by effect of iodine deficiency in pregnancy. ${ }^{3}$. In India it is also widely prevalent with different states giving rates of prevalence. About 200 million people are at the risk of IDD in our country. The survey conducted by the Central \& State Health Directorates, ICMR and medical Institutes have clearly demonstrated that not even a single State/UT is free from the problem of Iodine Deficiency Disorders. It is estimated that 71 million populations are suffering from goitre and other iodine deficiency disorders ${ }^{4}$. In J\&K the figures also vary from one place to another. A study by Zargar et al ${ }^{5}$ in 1995 reported a prevalence of about $45.1 \%$ in school going children. Because of the widely prevalent situation in the state, the present study was contemplated to find out the magnitude of the problem so that necessary recommendations are forwarded.

METHODOLOGY: The study was conducted in district Srinagar. 3070 subjects were screened. The subjects were aged 6-12 years from district Srinagar. Two stage cluster sampling was used to select the study sample. In the first stage a total of 30 clusters (Schools) were selected based on probability proportionate to the size of the target population in different zones. Thirty clusters were selected to ensure a valid estimate of the prevalence of the problem. In the $2^{\text {nd }}$ stage 103 children within each cluster were selected. The number of children per cluster was based on the estimated prevalence of $20 \%$ with $95 \%$ confidence interval with a relative margin of error $10 \% \&$ a design factor of 2 . The formula used to calculate the sample size used was:

$$
\begin{aligned}
& \mathrm{N}=\frac{(\mathrm{z} \alpha)^{2} \mathrm{Q}}{(\mathrm{L})^{2} \mathrm{P}} \\
& \text { Where } \mathrm{P}=\text { expected prevalence } \\
& \mathrm{z} \alpha=\text { standard normal deviate (corresponding to } \alpha \text { level of significance) } \\
& \mathrm{L}=\text { relative margin of error } \\
& \mathrm{Q}=\mathrm{I}-\mathrm{P}
\end{aligned}
$$

FINAL SAMPLE SIZE $=$ design effect $\mathrm{x} \mathrm{N}$

No of clusters $=30$

Sample size per cluster: Total sample size

Data were collected using a specially designed questionnaire, including information about name, zone, school, exact age of the child and sex. Clinical examination of the thyroid gland of each child was done through inspection and palpation. Classification of goitre grading was based on the criteria endorsed by WHO/United Nations Children's Fund/International council for the control of iodine deficiency disorders that is as follows:

$$
\text { O = No palpable or visible goitre }
$$


$1=$ A mass in the neck that is consistent with an enlarged thyroid that is palpable or visible with neck in extended position but not in neutral position. It also moves up in the neck on swallowing

$2=$ A swelling in the neck that is visible in a neutral position and is consistent with an enlarged thyroid when the neck is palpated

The sum of grades $1 \& 2$ was taken as total goitre rate.

OBSERVATIONS: Total children surveyed were 3070 in the 30 cluster (schools) of district Srinagar with 103 children in each cluster being surveyed. These accounted for about 1718 Boys\& 1352 Girls. The full details are depicted in the following Table1:

\section{TABLE 1}

\begin{tabular}{|c|c|c|c|c|c|c|c|c|c|}
\hline \multirow{2}{*}{$\begin{array}{l}\text { Age } \\
\text { in } \\
\text { yrs }\end{array}$} & \multicolumn{4}{|l|}{ Boys } & \multicolumn{3}{|l|}{ Girls } & \multirow[t]{2}{*}{ total } & \multirow{2}{*}{$\begin{array}{l}\text { Grand } \\
\text { total }\end{array}$} \\
\hline & G0 & G1 & G2 & Total & G0 & G1 & G2 & & \\
\hline 6 & 273 & 27 & & 300 & 168 & 22 & & 190 & 490 \\
\hline 7 & 222 & 37 & & 259 & 158 & 33 & 1 & 192 & 451 \\
\hline 8 & 209 & 25 & 2 & 236 & 149 & 25 & 3 & 177 & 413 \\
\hline 9 & 193 & 34 & & 227 & 148 & 25 & 1 & 174 & 401 \\
\hline 10 & 173 & 27 & & 200 & 143 & 28 & 3 & 174 & 374 \\
\hline 11 & 223 & 36 & 1 & 260 & 169 & 45 & 2 & 216 & 476 \\
\hline 12 & 190 & 44 & 2 & 236 & 183 & 43 & 3 & 229 & 465 \\
\hline & 1483 & 230 & 5 & 1718 & 1118 & 221 & 13 & 1352 & 3070 \\
\hline
\end{tabular}

As for as overall prevalence of grade $1^{\text {st }}$ goitre is concerned, we found that $14.69 \%$ of the children had grade $1^{\text {st }}$ goitre with figures higher in girls to the tune of $16.35 \%$ and in boys it accounted for $13.38 \%$. Grade $2^{\text {nd }}$ goitre was noticed in $0.59 \%$ of surveyed children being to the extent of $0.96 \%$ in Girls \& $0.29 \%$ in Boys. Total goitre rate (TGR) which is the sum of grade ' 1 st $\&$ Grade $2^{\text {nd }}$ was found to the extent of $15.27 \%$. In Girls the rate was higher to an extent of $17 \%$ as compared to Boys were it was $13.67 \%$. The relevant details are shown in table 2 and are graphically represented in figure 1 .

TABLE 2: Overall prevalence of goitre:

\begin{tabular}{|l|l|l|l|}
\hline Grade of goitre & Total $(\mathrm{M}+\mathrm{F}) \%$ & Boys \% & Girls \% \\
\hline G1 & 14.69 & 13.38 & 16.35 \\
\hline G2 & 0.59 & 0.29 & 0.96 \\
\hline TGR & 15.27 & 13.67 & 17 \\
\hline
\end{tabular}

Note: G1 = grade $1^{\text {st }}$ goitre, G2= grade $2^{\text {nd }}$ goitre,

$T G R=$ total goitre rate $(G 1+G 2)$ 


\section{ORIGINAL ARTICLE}

\section{FIGURE 1}

\section{Prevelance of Goitre}

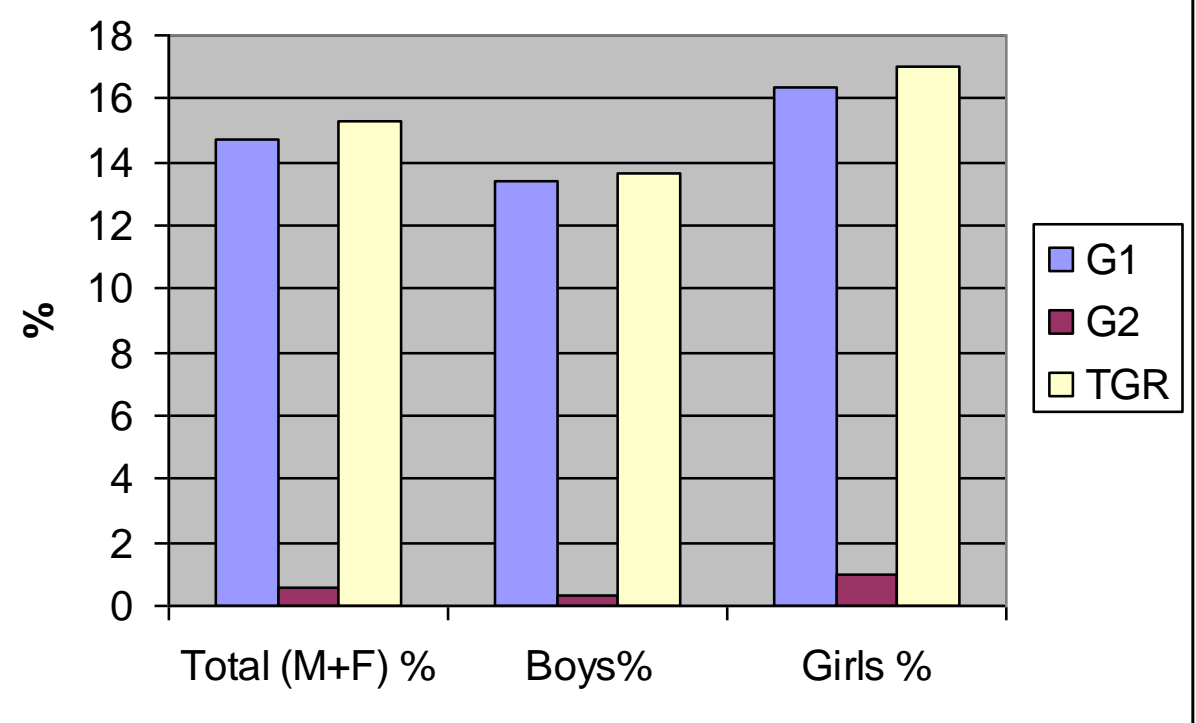

As regards magnitude of grade, $1^{\text {st }}$ goitre in different age groups as well as sex differentiation is concerned; the details are shown in table 3 . The table reveals that grade $1^{\text {st }}$ goitre was more common in the age group of 12 years were it was to the extent of $18.70 \%$ followed by age group of 7 years were it was $15.52 \%$. Concerning the sex differentiation it is evident from the table that the prevalence was more in age group of 12 years (18.64\%) followed by age group of 9 years were it was $14.97 \%$. In girls, the magnitude was found to be higher in the age group of 11 years were it was found to be $20.83 \%$ followed by age group of 12 years were it was $18.77 \%$. All these details are shown in Table 3 and are also represented graphically in Figure 2.

TABLE 3: Prevalence rate of grade $1^{\text {st }}$ goitre in different age groups as per sex

\begin{tabular}{|l|l|l|l|}
\hline Age group & Overall (M+F) \% & $\begin{array}{l}\text { Boys } \\
\%\end{array}$ & $\begin{array}{l}\text { Girls } \\
\%\end{array}$ \\
\hline 6 & 10 & 9 & 11.57 \\
\hline 7 & 15.52 & 14.28 & 17.18 \\
\hline 8 & 12.10 & 10.59 & 14.12 \\
\hline 9 & 14.71 & 14.97 & 14.36 \\
\hline 10 & 14.70 & 13.5 & 16.09 \\
\hline 11 & 17 & 13.84 & 20.83 \\
\hline 12 & 18.70 & 18.64 & 18.77 \\
\hline
\end{tabular}




\section{FIGURE 2}

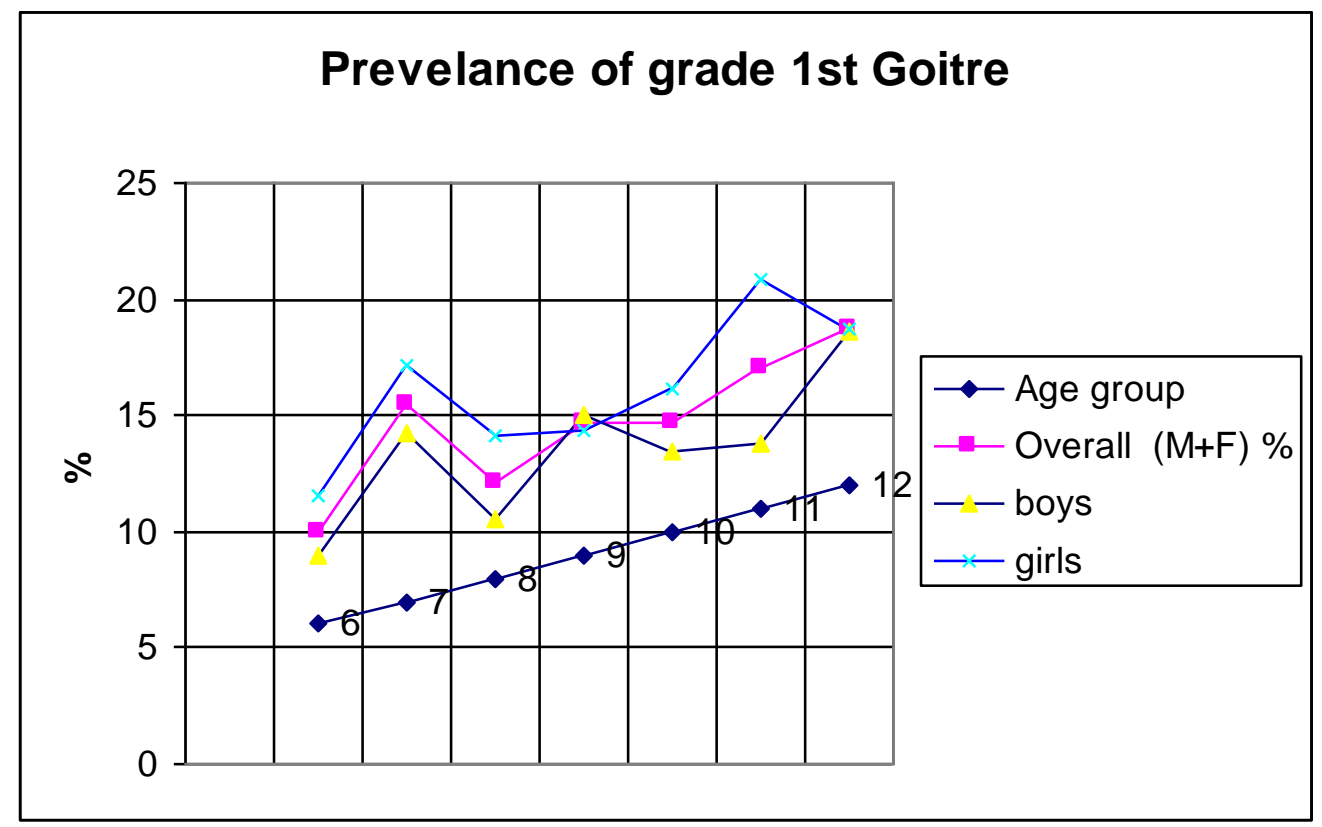

As regards total goitre rate as per sex \& age group, the relevant details are shown in table 4 . Analysis of the table shows that maximum rate was found in the age group of 12 years. In boys the maximum involvement was seen in age group of 12 years (19.49\%) followed by that of 9 years (14.97\%). In girls maximum incidence was found in age group of 11 year's $(21.75 \%)$ followed by that of 12 years $(20.08 \%)$

TABLE 4: Total Goitre Rate in different age groups as per sex

\begin{tabular}{|l|l|l|l|}
\hline Age group & Overall $(\mathrm{B}+\mathrm{G}) \%$ & $\begin{array}{l}\text { Boys } \\
\%\end{array}$ & $\begin{array}{l}\text { Girls } \\
\%\end{array}$ \\
\hline 6 & 10 & 9 & 11.57 \\
\hline 7 & 15.74 & 14.28 & 17.70 \\
\hline 8 & 13.31 & 11.44 & 15.81 \\
\hline 9 & 14.96 & 14.97 & 14.94 \\
\hline 10 & 15.50 & 13.5 & 17.81 \\
\hline 11 & 17.64 & 14.23 & 21.75 \\
\hline 12 & 19.78 & 19.49 & 20.08 \\
\hline
\end{tabular}




\section{FIGURE 3}

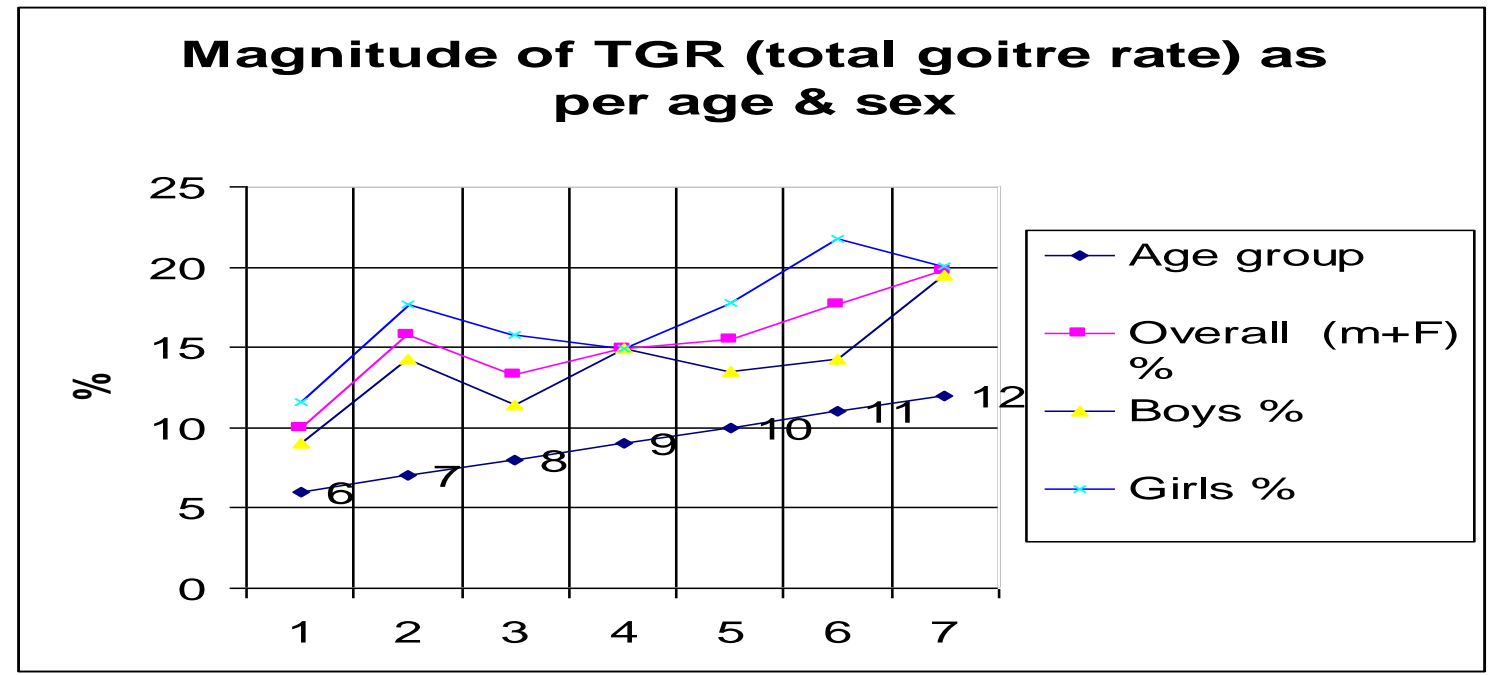

DISCUSSION: Goitre is still a big public health problem in developing countries. We found that $14.69 \%$ of the children had grade $1^{\text {st }}$ goitre with figures higher in girls to the tune of $16.35 \%$ and in boys it accounted for $13.38 \%$. Grade $2^{\text {nd }}$ goitre was noticed in $0.59 \%$ of surveyed children being to the extent of $0.96 \%$ in Girls \& $0.29 \%$ in Boys. Total goitre rate (TGR) which is the sum of grade ` 1 st $\&$ Grade $2^{\text {nd }}$ was found to the extent of $15.27 \%$. In Girls the rate was higher to an extent of $17 \%$ as compared to Boys were it was $13.67 \%$. Zargar AH et al $(1997)^{6}$ found the TGR to be $52.08 \%$ with G1 in $41.95 \%$ \& G2 in $10.1 \%$ in children of Baramulla district of Kashmir valley. The prevalence was more in boys to the extent of $52.08 \%$ \& in girls it was $49.23 \%$. In $1995^{5}$ in there study in school children aged 5-15 years they found a TGR of $45.2 \% .43 .9 \%$ in boys \& 46.23 in girls respectively.37.74\% of children had grade $1^{\text {st }}$ goitre while as $7.44 \%$ had grade $2^{\text {nd }}$ goitre. Our figures are lower possibly because of better awareness \& sustained IEC activities by the Government about the use of iodized salt and possibly because the age group included was lower. Kapil U et al (2003) ${ }^{7}$ in their study in school children aged 6-12 years which they did in Bharatpur district of Rajasthan found the rate to be $7.2 \%$. Grade $1^{\text {st }}$ goitre was seen in $7 \%$ \& grade $2^{\text {nd }}$ goitre in $0.2 \%$ of children. As for as sex is concerned the rates of $\mathrm{G} 1$ goitre was $5.7 \%$ \& $7.9 \%$ in girls \& boys respectively. Chandra AK et al (2001) 8 in their study in children aged 6-15 years found the TGR to be $21.6 \%$ with G1 in $20.2 \%$ \& G2 to be $1.4 \%$. Brahmbhatt S (2000) ${ }^{9}$ in their study in Dang \& Baroda districts of Gujarat found the TGR to be $29.6 \%$ with G1 in $29.2 \%$ \& G2 in $0.4 \%$. Our figures correlate well with there findings. Our figures also correlate with that of Bhardwaj AK et al (1997) ${ }^{10}$ who found the TGR to be $20.5 \%$ with G1 in 17.8 \& G2 in $2.7 \%$ of children aged $6-12$ years. The rate was found to be $39.3 \%$ in boys and $18 \%$ in girls.

Grade $1^{\text {st }}$ goitre was more common in the age group of 12 years were it was to the extent of $18.70 \%$ followed by age group of 7 years were it was $15.52 \%$. Concerning the sex differentiation it is evident from the table that the prevalence was more in age group of 12 years in boys (18.64\%) followed by age group of 9 years were it was $14.97 \%$. In girls, the magnitude was found to be higher in the age group of 11 years were it was found to be $20.83 \%$ followed by age group of 12 years were it was $18.77 \%$. in the study by Chandra et al ${ }^{8}$ in tripura the maximum involvement was seen in age group of 11 years to the extent of $24.1 \%$.our figures among boys are more probably due to screening 


\section{ORIGINAL ARTICLE}

of more boys than girls, since female education is not given much preference hence girls are not encouraged to be present all the times in school. As for as TGR in reference to age \& sex ,is concerned we found that maximum TGR (both sexes) was found in the age group of 12 years $\& 21.75 \%$ in the age group of 11 years in girls. Chandra et al (2001) ${ }^{8}$ found the TGR to be more in age group of 11 years in both he sexes. Kapil U et al (1996) ${ }^{11}$ found that TGR was maximum in the age group of 10 years in both sexes.

CONCLUSION \& RECOMMENDATIONS: Goitre is still a major public health problem in J\&K. although drastic decrease in the magnitude of the problem has occurred in few years. In this connection we would like to suggest the following measures.

- A Goitre cell needs to be established \& strengthening of the same with expertise from community medicine department. In this connection proper lab facilities for urinary iodine excretion as well as for checking the iodine content of salt. It is also essential to set up one district level IDD monitoring laboratory for iodine content of salt and Urinary Iodine Excretion for monitoring proper implementation of the IDD Control Programme. The iodized salt should be distributed through public distribution system also.

- Maximum IEC (Information, Education and Communication) involvement should be ensured so that people are made aware about the consumption of iodized salt. In this connection, help of field publicity wing \& Health Education Bureau also needs to be taken. To intensify the IEC activities a communication package by way of video films, posters/danglers and radio/TV spots need to be finalized

- The goitre prevalence rate although very high in district Srinagar yet it appears that the magnitude is lower as compared to other districts as per hospital OPD attendance. Thus to find the exact magnitude of the problem in whole Kashmir valley the survey needs to be done in other districts also.

- To prevent loss of iodization because of environmental loss what is needed is production facility in state also so that this problem is checked. Quality control of the salt with repeated lab investigations thus is very much needed.

\section{BIBLIOGRAPHY \& FURTHER READING}

1. Karmarker MG, Deo MG, Kouchpilli N et al "pathophysiology of Himalyan Goitre: Am J. clin Nutr. 1974;27:96-103

2. WHO : indicator for Assessing Iodine deficiency disorders \& their control through salt iodization" Geneva, WHO 1994 (Document no WHO/Nut/94.6)

3. Who: Micronutrient Deficiency Information system project, Global prevalence of IDD: Geneva, WHO ,1993 (MDIS working paper no 1)

4. website: www.mohfw.nic.in/IDDCP accessed in October 2012

5. Zargar AH, Shah JA, Mir MM, Laway BA. Prevalence of goiter in schoolchildren in Kashmir Valley, India. American Journal of Clinical Nutrition, 1995, 62(5) :1020-1021.

6. Zargar AH, Shah JA, Masoodi SR, Laway BA, Shah NA, Mir MM. Prevalence of goitre in school children in Baramulla (Kashmir Valley). Indian Journal of Pediatrics, 1997, 64(2) :225-230

7. Kapil U, Singh P, Pathak P, Singh C. Assessment of iodine deficiency disorders in district Bharatpur, Rajasthan. Indian Pediatrics, 2003, 40(2):147-149. 
8. Chandra AK; Ray I; Ray P "Studies on the current state of iodine nutrition of the school: age children in west Tripura, north east India" Indian Journal of Physiology and Allied Sciences.. 1997 Apr.; 51(2): 91-100

9. Brahmbhatt S, Brahmbhatt RM, Boyages SC. Thyroid ultrasound is the best prevalence indicator for assessment of iodine deficiency disorders: a study in rural/tribal schoolchildren from Gujarat (western India). European Journal of Endocrinology, 2000, 143(1):37-46.

10. Bhardwaj AK; Nayar D; Ramachandran S; et al "Assessment of iodine deficiency in district Bikaner, Rajasthan." Indian Journal of Maternal and Child Health. 1997 Jan-Mar; 8(1): 18-20

11. Kapil U, Saxena N, Ramachandran S et al : Assessment of iodine deficiency disorders using 30 cluster approach in the national capital territory of Delhi: Indian Pediatrics , 1996, 33(12):113-1017 